\title{
Exploring the Adoption and Usage of Learning Management System as Alternative for Curriculum Delivery in South African Higher Education Institutions during Covid-19 Lockdown
}

\author{
Bongani T. Gamede ${ }^{1}$, Oluwatoyin Ayodele Ajani ${ }^{1} \&$ Olufemi Sunday Afolabi ${ }^{2}$ \\ ${ }^{1}$ Department of Social Sciences Education, University of Zululand, South Africa \\ ${ }^{2}$ Department of Information Science, University of Zululand, South Africa \\ Correspondence: Dr Oluwatoyin A. Ajani, School of Social Sciences Education Studies, Faculty of Education, \\ University of Zululand, KwaZulu-Natal, 3886, South Africa.
}

Received: April 28, 2021

Accepted: July 14, 2021

Online Published: July 19, 2021

doi:10.5430/ijhe.v11n1p71

URL: https://doi.org/10.5430/ijhe.v11n1p71

\begin{abstract}
This study adopted a discursive approach to review the use of the Learning Management System (LMS) popularly known as 'Moodle' in most South African universities. Moodle as fondly called is one of the online tools that can be effectively used to deliver learning activities as well as online learning assessments to implement curriculum delivery without borders or disruptions during the COVID-19 lockdown across the globe. The author highlights various extant studies on the usage and adoption of LMS into teaching and learning for effective implementation in higher institutions of learning. LMS is a global online tool that has been in use for decades in various higher institutions of learning across the developed countries. It has proved to be an efficient learning platform that has impacted significantly the education sector in these developed countries, as learning experiences are provided to diverse students at their comfort zones. With the break of the COVID-19 pandemic that affects the global world, teaching and learning in most parts of the developed countries continue to be facilitated through various online approaches that include LMS in the developed countries. Unfortunately, the pandemic lockdown in many developing countries like South Africa grossly impacted the delivery of curriculum and educational activities in various learning institutions for several months. The continuous presence of COVID-19 led the South African Department of Higher Education and Training to review approaches to curriculum delivery to salvage academic activities. Thus, declared online learning as an alternative to face-to-face curriculum delivery in higher institutions. The adoption of LMS results as the best approach to engage students in full teaching and learning activities.
\end{abstract}

Keywords: COVID-19, LMS, teaching, online learning, higher institutions, lock-down, curriculum delivery

\section{Introduction}

Adoption of Learning Management System (LMS) as an approach to curriculum delivery in the education system took a new dimension as a critical tool globally during the COVID-19 pandemic. The advent of COVID-19 in December 2019 from a Wuhan city, China took the whole world by surprise, as many countries were grounded to full lockdown to control the spate of infection that has resulted in several death (Jansen, 2020; Huang, 2020). The WHO warned the global world of the imminent dangers of the COVID-19 pandemic, and recommended wearing of face masks, social distancing, frequent washing of hands or use of alcoholic based sanitiser for hands to prevent the spread of the deadly virus (Ellis, 2020; Huang, 2020). With the lockdown, educational institutions in South Africa were shut down to prevent the large gathering of people as stipulated in the regulations for lockdown. Despite the lockdown, the cases of infection and death became unabated due to some factor. "Social distancing as a mitigating factor did not take account of crowded human settlements. Restriction of the number of mourners at funerals was made without attending to rituals of mourning and meaning-making in communities. The return of children to schools was gazetted without insights into how schools function as organisations and what that implies for re-opening under strict conditions. Enforcing lockdown regulations was often done with little regard for the values of the Constitution and the rights of citizens. These were not issues that could be resolved using epidemiology data alone" (Jansen, 2020:1).

Thus, the Department of Higher Education and Training (DHET, 2020) advises higher education institutions to shift to online learning to continue teaching and learning activities instead of traditional face to face activities. Govender 
(2020) avows the paradigm shift from the traditional face to face curriculum delivery to the online approaches to reach students at their convenience, thus making teaching and learning effectively. Mlitwa and Belle (2011) opine that South African learners need to fully embrace LMS to access learning activities effectively. The Council on Higher Education (CHE, 2020) avows that LMS' adoption and use among students remain underutilized in many South African universities. Furthermore, Steyn et al. (2018) affirm that the usage of online learning platforms in historically disadvantaged South African higher education institutions is lower than the white-dominated universities' usage in South Africa.

QS (2020) reports that the culture of using LMS for curriculum delivery among some academics from developing countries differ from those in developed countries. This implies that the effective use of LMS in most African universities does not allow the students to explore curriculum contents. Extant literature affirms the South African government's commitment and vision for students to explore learning materials through diverse online learning platforms (Cloete, 2017; CHE, 2020; DHET, 2019, 2020). Gurstein (2011), Coleman and Mtshazi (2017) call for massive adoption of LMS by the university academics to deliver learning activities. In a longitudinal study conducted by Sackstein, Coleman and Ndobe (2019), these authors declare that academic staff's perceptions of adoption and integration of the LMS for curriculum delivery in the historically disadvantaged South African higher institutions affect the efficiency of LMS as online learning. However, Evans and Mutula (2015) encourage academics to fully adopt and integrate LMS for the delivery of various contents of all modules to enhance teaching and learning. This implies that the adoption and integration of the LMS, enable students to be engaged and provided with learning materials at their comfort zones.

\section{Theoretical Framework}

The use of an appropriate theoretical framework in any study is to underpin the study with a framework that analyses the phenomenon for in-depth understanding. Thus, the adoption of an appropriate theoretical framework for this study is to strengthen the discursive understanding of the study. Various learning technologies are being employed globally in the education system to enhance efficiency and productivity, however, there exists a significant resistance especially among academics in developing countries. Technology acceptance theories are usually adopted into various studies that relate to online learning or the use of learning technologies, by different scholars, in an attempt to promote the use of technologies in education (Mutsvunguma, 2019).

The study adopts the Unified Theory of Acceptance and Use of Technology (UTAUT) and Diffusion of Innovation Theory (DOI) theories to underpin the use of LMS as online learning during COVID-19 lockdown. These theories explain why academics should adopt LMS to deliver learning contents in higher institutions, especially during the COVID-19 pandemic, which restricts social gathering in large numbers.

\subsection{Unified Theory of Acceptance and Use of Technology (UTAUT)}

This theory is a technology-driven model that was developed by Venkatesh, Morris, Michael, and Davis in 2003. The Unified Theory of Acceptance and Use of Technology (UTAUT) appropriately explains the key concepts that can enhance the effective use of technology in any organisation. Bhatiasevi (2016) asserts that UTAUT is efficient in promoting an in-depth understanding of technology adoption and integration among groups of people in an establishment. According to Bhatiasevi (2016), the theory provides more clarity for technology acceptance in any study than other similar theories, thus making it significantly appropriate for this study. Seemingly, Venkatesh et al. (2003: 428) posit that "various previous technology acceptance models have described an intention to use technology at 40 per cent among the technology users while UTAUT describes the intention to use technology among the technology users at 70 per cent". Hence, the adoption of the UTUAT model in any study strengthens the study with the systematic combination of eight key theories that distinguish UTAUT as an appropriate theory that comprehensively describes the use of various technology in any organization (Quigfei, Shaobo \& Gang 2008).

The model provides in-depth clarity on why users adopt and will use technology effectively despite variables that affect its use; hence, UTAUT is rich and significantly reliable to underpin any study (Bhatiasevi, 2016). According to Venkatesh et al (2003: 429), "the model has four constructs that have been adapted to explain different factors influencing the behavioural intention of academics to use Moodle in this study. These constructs are performance expectancy (PE), effort expectancy (EE), social influence (SI) and facilitating condition (FC)".

Evans (2013) asserts that the application of UTUAT's key constructs controls variables such as age, gender, the experience of those likely to use technology. Ventakatesh et al., (2003: 429) describe "the constructs as performance expectancy (PE) as a user believes that using technology to perform a job function will promote his performance, effort expectancy (EE) refers to the level of ease at which a user uses technology to perform a function. Furthermore, 
social influence (SI) explains the perception of a user to use a technology based on how important the technology is to him to use the technology to perform a function, while the facilitating condition (FC) refers to the degree at which a user believes that organizational facilities enhance the use and adoption of such technology". Scholars avow that UTAUT' suitability, appropriateness, richness and reliability enhance the adoption and use of technology for effective curriculum delivery in higher education institutions, especially in the present global pandemic era, making learning activities available to students without borders (Holtz \& Krein 2011; Jeng \& Tzeng 2012). Other studies have been conducted using UTAUT to affirm the efficiency of UTAUT in the adoption and use of technology for learning activities in different learning contexts in higher education institutions (Evans, 2013; Owolabi, 2016; Quadri \& Garaba, 2019).

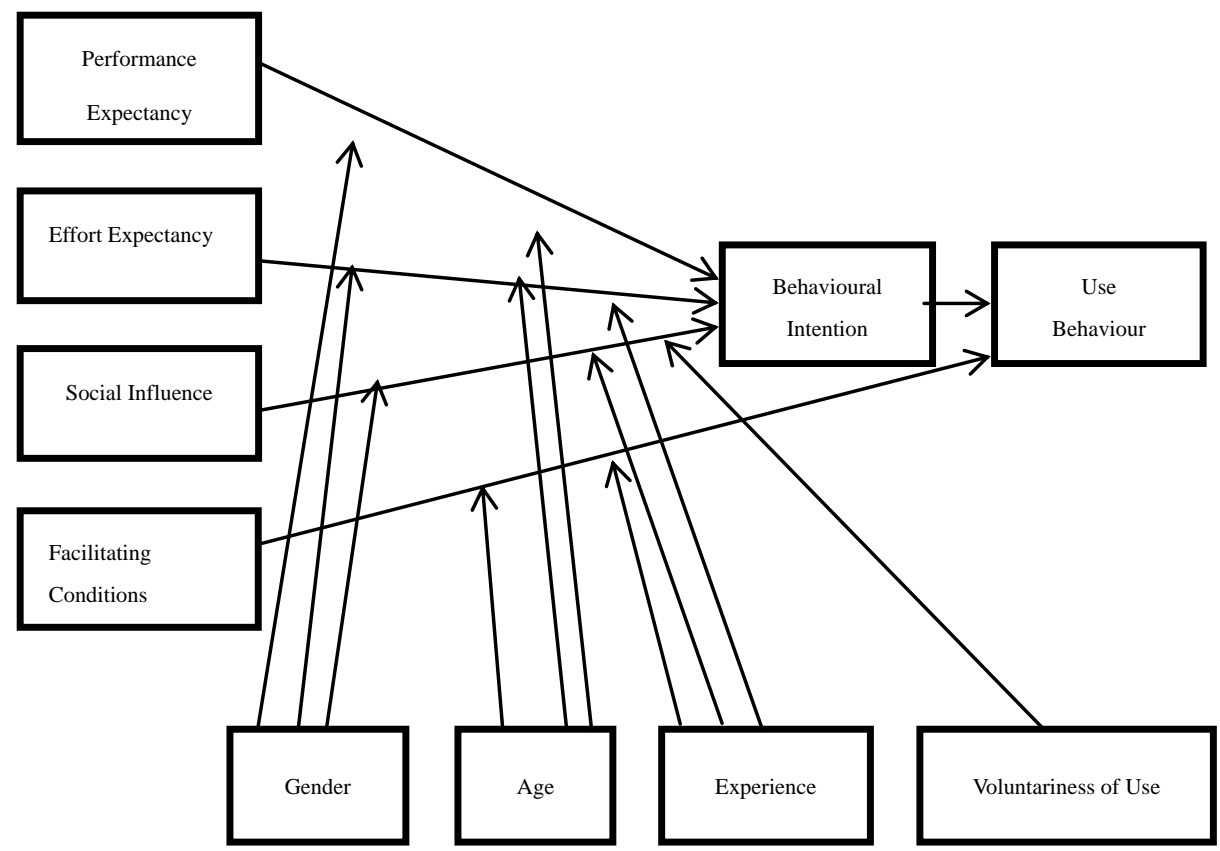

Figure 1. UTAUT Model (Venkatesh et al. 2003)

According to the various extant literature, UTAUT is a suitable framework that establishes or explains how behavioural intention can be influenced to enhance the usage of technology for teaching and learning by academics. The key constructs of UTAUT are described to underpin the theory, according to Venkatesh et al. (2003:428), "Performance Expectancy is the degree at which an academic staff believes that the use of Moodle LMS will promote curriculum delivery; Effort Expectancy refers to the degree at which any academic staff believes that Moodle LMS will be easy to deliver curriculum; Social Influence is the academic staff's perception that every other academic staff should use Moodle LMS for curriculum delivery; Facilitating Condition which is the degree at which academic staffs believes that organizational and technical facilities are available to use Moodle LMS for teaching and learning".

\subsection{Diffusion of Innovation (DOI) Theory}

The study adopts another relevant theory to strengthening the technology acceptance of LMS among higher institutions' academic staff. The Diffusion of Innovation is a relevant underpinning theory for the use of LMS. According to Everett Rogers who developed this theory in 1962, the DOI theory is a diffusion model that can be applied to technology adoption and integration in any establishment. It explains or describes the idea behind the acceptance of LMS innovation by a group of users. Rogers (1962) describes the usage of technology as an innovation that involves technological innovations. Similarly, Gikenye (2012:45) avows "that innovation can be a technological technique or an idea that can be adopted by a group of people in any social system". Therefore, the theory provides clarity on acceptance of innovation such as LMS, gaining momentum or relevance among a given group of people. The final point of diffusion theory is its ability to convince individuals to accept and use the innovation. Thereby making the academics adapt effectively to the use of LMS for the delivery of learning activities. The academics need to perceive the significance of the innovation for them to fully adopt the LMS for curriculum delivery. 
Rogers (2003) affirms that for any innovation to be adopted for effective diffusion in any organization it comprises five significant constructs. The constructs are compatibility, relative advantage, Trialability, Observability and complexity. Accordingly, Rogers (1962) admits that to adopt an innovation expressively among the academics, the ease of use and diverse benefits of the innovation is critical to its effective usage. This infers why academic users can adopt LMS as a new technology for curriculum delivery in developing African countries or reject its use. Adopting an idea can influence academics' approach to use LMS or any other technology in a different approach for teaching and learning, compare to those who reject such an idea. This specifies why delivering course contents or a module by an academic can be enhanced to provide learning materials through LMS to his students. Thus, to promote the usage and adoption of LMS among academic staff, the target population must be identified. Seemingly, Rogers (1995) and Surry (1997) assert that four significant factors influence the diffusion of innovation. The factors maintain that necessary information on the innovation must be made available to the supposed users, taking into consideration the contexts of the social system that the innovation is designed for.

According to Roger's Diffusion of Innovation theory, different categories of the adopters of innovation are classified chronologically as the innovators, early adopters, early majority, late majority and laggards.

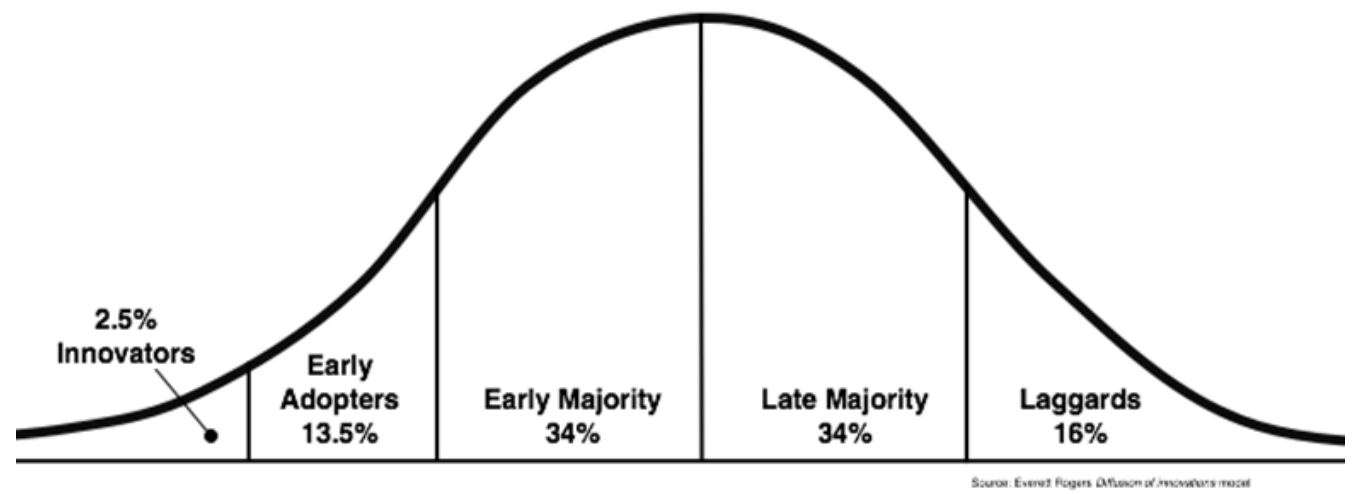

Figure 2. Source: "http://blog.leanmonitor.com/early-adopters-allies-launching-product/"

As shown in the above figure, most of the adopters of technology are found in the middle categories. This explains why during the promotion of innovation, various strategies are employed to convince a different group of adopters. Hence, an individual or collective group or authority-based individuals may decide to adopt or accept innovation.

This highlights why individually motivated or organizational-driven factors can enhance or debar the use of LMS fully or effectively by the academic staff members for teaching and learning. "Its provision for basic analysis on the basic components of technological innovations, the adoption, diffusion and communication" (Mkhize, Mtsweni \& Buthelezi, 2016:298). Also, several studies have used the DOI theory in different contexts to affirm its appropriateness in underpinning the global acceptance of ICT innovations in the education system (Harris, 2002). The theory recognizes the pace of diffusing technology among the users in the education system, which can be slow or accepted late. Thus, highlighting the significant potentials of innovation of LMS for quick adoption.

\section{The Use of Moodle, as An Effective Learning Management System}

A Learning Management System (LMS) is a platform that provides teachers or facilitators of learning to design, manage, organize and present learning materials for online access of students or learners. LMS is used for the delivery of learning materials, curriculum contents, assessments and interactive activities between the facilitator and the students/learners (Mpungose, 2020). LMS is a broad streamlined system that provides a central location or platform where learning materials can be accessed online and contents can be developed for users' usage (Mpungose, 2017). LMS software is globally used in basic schools, higher education institutions, school management districts, etc. A learning management system is simply the platform for the storage and delivery of learning materials/activities. LMS comprises over one hundred platforms such as Google Classroom, Moodle, Schoology Learning, Blackboard Learn and many others.

Moodle is one of the prominent LMS in higher education institutions and is an open-source for many educational institutions. Moodle is a project that is administered in Australia as the Moodle Project, by Moodle HQ. Its global acceptance in most higher education institutions is based on its functionality as an effective platform for teaching and learning without borders. The advent of the Fourth Industrial Revolution has strengthened the education system with 
the use of Moodle as an effective platform for teaching and learning (Mpungose, 2020). According to Mpungose (2017), it is a key transformative tool in this technology era and also a good platform to maximize the teaching and learning (TAL) process. This is E-learning in the education system and enhances effective curriculum delivery through the provision of diverse learning materials to suit students' learning exploits, to strengthen face-to-face (blended learning) or serve as distance learning. The use of different electronic platforms to disseminate knowledge is known as e-learning. According to Al-Busaidi (2013) and Kibinkiri (2014), e-learning employs various learning technologies/platforms to engage students either as online and offline modes or both, internet and intranet.

Similarly, Kent, Laslo and Rafaeli (2016) affirm e-learning as a learning approach that is computer-assisted to enhance teachers' pedagogical approaches; for effective teaching and learning (TAL) experiences between the teachers and students, and vice-versa. Ohei and Brin (2019) posit that integrating learning technologies that are electronically driven into the higher education space is an innovative idea that is being embraced by various higher education institutions. The invasion of e-learning for curriculum delivery in teaching and learning in different developing countries became enhanced as a result of the COVID-19 lockdown, which restricts social gatherings to control the pandemic.

E-learning has significantly enhanced teaching and learning activities globally, and many developing countries are embracing e-learning fully as an alternative to face-to-face learning in HEIs (Mwalumbwe \& Mtebe, 2017; Ratheeswari, 2018; Zhou, Chen \& Chen, 2019). The borderless classrooms, ease of access, removal of location barriers, effective online learning, student's regular engagement, diverse self-paced learning, online interactive platform, as well as instant feedback are some of the benefits of e-learning. Mpungose $(2017,2020)$ asserts that e-learning provides adequate support for academics to deliver course contents, curriculum details, learning activities or assessments to students. The adoption of e-learning platforms allows time flexibility for the users while their locations are never a barrier to access online learning and interactions with academics (Islam \& Azad, 2015). Furthermore, Naresh and Reddy (2015) affirm that the adoption and integration of Moodle into higher education institutions in most developed countries have been for decades. Thus, the long advent of the various technological approaches/platforms has increased quality access to learning in these developed countries (Martins \& Nunes, 2016).

However, the announcement of a national lockdown by President Cyril Ramaphosa in March 2020, led to the shutting down of all educational institutions. The adoption of Moodle as online learning for curriculum delivery was embraced as the best option to continuing teaching and learning, while the restriction on social gatherings lingers on, due to the pandemic (Mhlanga \& Molo, 2020). Several scholars have established in various longitudinal studies, the use of Moodle as LMS in some selected universities in South Africa years to complement face-to-face classroom teaching before now (Bagarukayo \& Kalema, 2015; Schutte et al., 2017; Letseka, Letseka \& Pitsoe, 2018; van de Heyde \& Siebrits, 2019). However, with the emergence of the COVID-19 pandemic, many HEIs had to adopt Moodle for full delivery of learning activities nationwide.

Poon (2013) avows that online learning and traditional physical classroom are approaches that some universities have been used to as blended learning approach. It is an approach that uses different ICT tools to deliver learning materials/activities to students. Blended learning has been established as very effective in presenting knowledge, information and skills, in which academics can engage students in various learning activities, that all students participate at their own pace; better driven by the teachers (Atef \& Medhatl, 2015; Ma, Li \& Liang, 2019). Similarly, Han and Shin (2016) agree that the introduction of various learning technologies which include Moodle has improved students' quest for learning, especially in higher institutions. The development of Moodle as a learning software has eased curriculum delivery.

Hence, utilization of this Moodle by various academics to deliver learning in higher education institutions is capable of providing students with diverse access to learning at their own self-paced in different locations Macfadyen and Dawson (2010) opine that the integration of Moodle into learning, enhances students' online learning activities to be easily monitored. Alghamdi and Bayaga (2016) agree that the use of Moodle enables academics to design, organize and deliver contents of their modules in an interactive approach to engage their students. The adoption of Moodle during the pandemic is a good approach for curriculum delivery as it does not allow physical contacts between the academics and their students (Murshitha \& Wickramarachchi, 2016).

However, effective use of Moodle by the facilitators and the students anchors on the availability of all the technological resources that can necessarily provide users with the needed technical support. This is why Mtebe and Raisamo (2014) call for the professional development of academics to effectively adopt and use Moodle in African universities. Seemingly, Emelyanova and Voronina (2014) agree that to increase the adoption of Moodle in most developing African higher institutions, there is a need for continuous capacity building for the academics to align 
their perceptions to the usefulness of the Moodle. This will enhance ease of use, develop a positive attitude towards the adoption of Moodle among academics (Alharbi \& Drew, 2014). Goh (2013:89) in his view, posits "that academics play a significant role in promoting and enhancing Moodle among their students as an electronic learning system. This implies that academics have a huge role in the acceptance and use of Moodle for effective curriculum delivery in higher education institutions".

The integration of Moodle into teaching and learning is a welcome global trend, which aims at promoting quality and enhanced TAL process, with the provision of necessary support to the academics for effective usage (Rhode et al. 2017; Lin, Wang, Wu \& Chen, 2019). Lansari et al., (2010) avow inclusion of learning technologies into the education system is to improve teaching and learning, and also to encourage competitive advantage. Duygu and Sevgi (2013) declare in Maina and Nzuki (2015) that many HEIs in Africa are yet to successfully integrate Moodle into teaching and learning due to some hiccups, and this is worrisome at this global age. Webbstock and Fisher (2016) also declare that diverse learning technologies are yet to be explored in many South African institutions to enhance TAL. This implies why some South African Universities are still making concerted efforts to transform the teaching and learning process (Heyde \& Siebrits, 2019). Hence, the present pandemic challenges call for the use of Moodle by academics for teaching and learning activities. Academics should be provided with all necessary support to maximize Moodle for curriculum delivery in various institutions of learning.

Webbstock and Fisher (2016) assert that Moodle's successful adoption is facing lots of challenges. Bhalalusesa et al. (2013) also agree that many higher education institutions in many parts of Africa fail to efficiently use Moodle to deliver curriculum or course contents. This is why many academics in Kenya, Nigeria, South Africa, Ghana, and Zimbabwe among others (Webbstock \& Fisher, 2016). Seemingly, Masiello, Ramberg and Kirsti (2005) highlight several factors influencing technology use and adoption in many African countries. These include inadequate basic technical skills, poor policy implementation and lack of technological resources. Similarly, Eynon (2005) agrees that ICT for self-efficacy is poor, technophobia, lack of computer literacy, gender, age affect the integration of Moodle in Africa.

In another longitudinal study conducted by Bervell and Umar (2017), Moodle is given prominent recognition as an effective tool for curriculum delivery in an effective manner in developed countries. Nair and Patil (2012) affirm that Moodle's implementation approach in African universities is weak to ensure effective adoption among the academic staff. Learning materials on Moodle is accessed by students based on their behavioural intention to use Moodle. The students access Moodle for various learning materials through their computers, mobile phones, tablets. It is the responsibility of the academics to provide activities on Moodle for students to engage in online learning, group discussions/forums as well as interact with the lecturers. These also make the academics adequately use Moodle to engage their students, which describes the significance of this study to enhance Moodle in South African universities.

\section{Adoption of LMS for Online Learning during COVID-19 for Curriculum Delivery in Higher Institutions}

The adoption of Moodle in different higher institutions of learning is a significant tool for e-learning activities (Embi et al, 2011; Alenezi, 2018). It is significant to advance teaching and learning activities and to make learning available to students at their own convenient time and locations (Kasim \& Khalid, 2016). Moodle is a convenient platform that enables academics to make available to their students' new teaching and learning environments via the internet and intranet (Zaharias \& Mehlenbacher, 2012).

The conventional face-to-face learning activities with LMS is known as blended learning, which is commonly adopted in some HEIs in Africa shifted to fully virtual learning activities to continue teaching and learning during the COVID-19 pandemic. Thus, students are provided with diverse learning approaches to interact, participate and engage themselves in virtual learning activities, at their self-paced and comfortable locations (Govender \& Mkhize, 2015). Therefore, using Moodle as one of the LMS is significantly beneficial to TAL activities. There is a need for academics to be supported with necessary technological infrastructures and continuing professional development on effective use of the resources among academics. "Different types of LMS can be used at higher education institutions, which include Moodle, WebCT, MyGuru2, iLearn System, PutraLMS, and MyLMS, Blackboard" (Kasim \& Khalid, 2016: 58). Therefore, the LMS is a good innovation that enables challenges of delivering curriculum contents in the present global COVID-19 pandemic, which calls for social distancing and restrict large gatherings.

Various studies have established how universities in the developed countries have been able to maintain teaching and learning during the pandemic, with the use of LMS to deliver learning activities/materials at various phases of their higher education system (Edutechnica, 2015). Some institutions of learning in some parts of Africa have also been reported using LMS actively for teaching and learning (Sakai, Atuto, Kewl \& Blackboard, 2011). Machado and Tao 
(2007) classify LMS into various types based on usability, availability, scalability and interoperability. Seemingly, Ulker and Yilmaz (2016) opine that LMS implementation can be successful if its cost, usefulness and suitability provide ease of adoption to the university academics. This implies that the role of motivational factors is critical to academics' use of LMS for teaching and learning effectively.

The Open Source (OS) is another significant type of LMS, which is accessible free and can be easily modified according to users' needs. Dobre (2015) further identifies LMS as the open-source, proprietary and cloud-based categories. The open-source consists of LMS software applications that adopt open source codes (computer codes), which can be modified and improved to present contents to students according to the facilitators' choice of the curriculum delivery. "The software provides efficient and alternative ways to promote academic learning at a relative cost as well as unrestricted access to academics to design their curriculum content delivery on the LMS (Feller \& Fitzgerald, 2000: 60). A good example of the open-source LMS is the common Moodle used by the universities in South Africa.

Moodle was developed in 2002 as a free Open Source software package to support curriculum content delivery, online learning materials, online assessments and tasks. In its creation, the common pedagogical principles are adopted to create interactive and effective online platforms suitable for teaching and learning activities (Subramanian, Zainuddin \& Alatawi, 2014). The software is free to users under the public license but the copyright to access is maintained while using, recodifying and customizing. Access to Moodle is internet-facilitated through any device which includes a laptop/computer, smartphones, and tablets. Both academics and students can access Moodle at different locations for learning activities that include assignment submission and management, quizzes, blogs, forums and tracking of student's attendance. The use of Moodle allows the creation of collaborative learning platforms for the facilitators and the learners to design/access learning contents, and can also be used to track students' understanding and assessments. "Moodle also promotes self-enrollment opportunities for students to access all learning materials, interact with other users and also join forums to communicate with built-in message system" (Sumak, Polancic \& Hericko, 2010:20).

The adoption of a variety of LMS in different HEIs in most developed countries shows the level of acceptance of LMS in higher education (Mkhize et al, 2016; Gasaymeh, 2017; Mtebe \& Raphael, 2018). According to Edutechnica (2016), it is reported that over $90 \%$ of Australian and Canadian universities use various LMS actively in curriculum delivery. Similarly, Zawaidy (2014) posits that many Saudi Arabian academics maximize LMS effectively for teaching and learning. Notably, the adoption of various LMS for curriculum delivery is gradually being incorporated into many HEIs in Africa on a large scale. Munguatosha et al. (2011) report in their longitudinal study that $80 \%$ of Tanzanian institutions are actively using diverse LMS to deliver learning contents. Conversely, other extant studies report that international organizations such as the African Development Bank Group (AfDB), United Nations Development Program (UNDP) and World Bank have continued to advocate for the mass adoption of LMS in Africa to enhance curriculum delivery; by providing training and support to academics and students on LMS (Trucano, Farrell \& Isaacs, 2007).

In 2012, the United States provided a \$15.6 million grant to African Virtual University (AVU) through the African Development Bank to improve e-learning for teaching and learning at all African universities (Adkins, 2013). As a result, many South African institutions are adopting a variety of e-learning platforms for curriculum delivery, according to the Department of Higher Education and Training, DHET (2013). Bhalalusesa et al (2013) and Elmubark et al. (2013) assert that LMS is becoming more integrated into teaching and learning in many HEIs in Africa. Mtebe and Raisamo (2014) report that only four institutions in Zimbabwe use LMS for teaching and learning. While Unwin et al. (2010) report in a survey study of 358 participants from 25 different HEIs in African countries, that only $49 \%$ of African universities use LMS in teaching and learning. In another study in Nigeria, diverse e-learning systems are employed by the National Open University of Nigerian (NOUN) to deliver learning contents (Ajadi et al, 2008; Suleiman 2011). The studies affirm that several factors influence the adoption and use of LMS in various parts of Africa (Sancheza \& Hueros, 2010; Sumak, Hericko, Pusnik, \& Polancic, 2011; Kumar \& Samalia, 2015; Suradi \& Yusoff, 2018). Kunene (2020) highlights these key factors as system trust, perceived ease of use and users' satisfaction among academics. Therefore, academics' use of Moodle for teaching and learning in most African countries are influenced or impaired by several factors.

\section{Challenges Facing the Use of Moodle in African Countries}

Several factors have been identified as challenges to the adoption or effective use of LMS in many HEIs in Africa, especially during the COVID-19 pandemic lockdown (Mpungose, 2020; Maphosa, Jita \& Dube, 2020; Kumar, Charan \& Venkatamuni, 2020; Mlaba, 2020). These studies reveal that students in HEIs in different parts of Africa 
experience diverse challenges in accessing or using LMS as the only adopted alternative to face-to-face classes or blended learning approaches before the lockdown. Gratz and Looney (2020) report that students in developed countries such as the United States of America do not experience the same problems with their African counterparts. According to Gratz and Looney (2020) academics in the United States of America lack adequate time to prepare the online learning materials or contents for their students, while students too, could not dedicate enough time to access LMS. Arora and Srinivasan (2020) identify issues of the network, lack of computer skills, lack of adequate awareness, and few students' attendances as some of the challenges to effective use of LMS. Moreover, Kaup et al. (2020) describe inadequate computer knowledge, lack of adequate training for academics and students to engage LMS effectively for teaching and learning as hindrances during the COVID-19 pandemic.

Thus, there is a case of digital divide or inadequate access to LMS resources such as internet connectivity, configured laptops and a conducive environment for some academics. Verma et al. (2020) avow that some academics need to be well trained to remotely deliver curriculum online only during the COVID-19 pandemic. The pandemic necessitates academics to facilitate online teaching and learning activities with their students from the comfort of their homes, however, technological challenges affect the efficiency of some aged academics who lack the technical expertise (Sharma, 2020). It is observed by some academics that many students do not take online serious while some of these students even play music during online classes (Punit \& Qz.com, 2020).

Buabeng-Andoh (2012) agrees that academic structures, institutional cultures and available resources create some barriers that influence academics' use of LMS for teaching and learning activities. Lloyd et al. (2012) report that various barriers such as institutional, interpersonal, facilities, computer literacy challenge effective online learning in some of the south-Eastern HEIs in the United States of America. Haber and Mills (2008) further declare inadequate training, the size of HEIs, as well as the complexity of learning contents, challenge the effective use of LMS in Florida.

Al-Senaidi et al. (2009:577) opine that "lack of necessary equipment, lack of adequate institutional support, users' perceptions on the benefits of Information and Communications Technology (ICT), lack of subject confidence and inadequate time are some of the barriers against online teaching and learning in Oman". Similarly, Berge and Mrozowski (1999) identify several factors that hinder the use of several online platforms for curriculum delivery to include technical resources, students' computer literacy, fiscal policy, geographical locations, governance, legal, labour management, cultural and academic structures. Other factors that can affect academics' adoption and usage of LMS may be driven by negative attitude, inadequate time, ICT competence, lack of necessary technological support for the academics and computer self-efficacy (Peralta \& Costata, 2007; Keengwe et al., 2008; Yuen \& Ma, 2008; Chen, 2010; Prottas et al., 2016; Mthethwa-Kunene, \& Maphosa, 2020). It is established that many African institutions do not have adequate support or resources that can be maximized by their academics to enhance quality online learning for the students (Taylor, 2002).

\section{Conclusion}

Moodle is one of the LMS tools that is used in the education system. The advent of the COVID-19 pandemic has shown that Moodle is an effective approach to continuing teaching and learning despite restrictions on social gatherings for various activities in a different part of the world. However, most African countries are facing challenges to effectively use Moodle for teaching and learning. Academics in various higher education institutions in Africa need the necessary support to maximize the use of Moodle for curriculum delivery, especially during the present COVID-19 pandemic lockdown. The pandemic has restricted large physical contacts, which was the order of the day for face-to-face classroom teaching. The continuity of academic activities during the pandemic is assured with the adoption of Moodle, to salvage the education system. Hence, Moodle has been established by various studies as an effective approach for curriculum delivery to students without any barrier. This study highlights the significance of using Moodle by academics to deliver learning materials/activities in South African universities. The study agrees with extant literature that Moodle as an effective LMS platform will benefit academics in designing and presenting various Module/course contents, as well as assessments to their students. The study concurs that various challenges mitigate the effective adoption of Moodle in many South African universities, just like other African universities. However, these challenges should be addressed by the universities to enhance the use of Moodle by academics.

\section{Recommendations}

Enhancement of Moodle as an LMS platform in many South African higher institutions is the focus of this discursive study. The study explores findings from extant studies (Elmahadi \& Osman 2013; Mtebe \& Raisamo 2014; Mpungose, 2017, 2018; Kumar et al, 2020; Mpungose \& Khoza, 2020; Maphose, Jita \& Dube, 2020) to recommend 
strategies to enhance effective use of Moodle among the lecturers in South Africa (Tagoe, 2012; Bhalalusesa et al, 2013; Chioma et al, 2018). The integration of Moodle into teaching and learning by the academics should be encouraged to deliver curriculum during the COVID-19 pandemic.

$>$ The Department of Higher Education and Training in South Africa should provide adequate fund to HEIs to provide necessary resources for Moodle. The existing teaching and learning policy frameworks for online learning should be revised to accommodate all technical support for the academics on e-learning. The revised policy will support the academics on maximum use of Moodle for all learning and assessments.

$>$ There is a need for continuing professional development of academics to attain adequate use of technology in education to promote the Fourth Industrial Revolution (4IR). The professional development of academics needs to be adequate and regular to address quality online teaching, online classes and assessments. Ajani (2019) affirms that professional development empowers academics for online teaching and assessments.

$>$ Lack of technical resources, as well as interrupted internet connectivity, remain serious challenges to the HEIs and academics in South Africa. Public-private partnerships can be encouraged to provide adequate technological resources to HEIs.

$>$ Designing of HEIs' curriculum for both conventional teaching and online teaching, to accommodate the integration of learning technologies for curriculum delivery. The curriculum should be well developed for online curriculum contents and assessments. These are designed to promote sustainable development goals.

\section{References}

Ajadi, T., Salawu, O., \& Adeoye, F. (2008). E-learning and Distant Education in Nigeria, Turkish Online Journal of Educational Technology, 7(4), 61-70.

Ajani O. A. (2019). Understanding Teachers as Adult Learners in Professional Development Activities for Enhanced Classroom Practices. AFFRIKA Journal of Politics, Economics and Society, 9(2), 195-208. https://doi.org/10.31920/2075-6534/2019/9n2a10

Alenezi, A. (2018). Barriers to Participation in Learning Management Systems in Saudi Arabian Universities. Education Research International, 2018. https://doi.org/10.1155/2018/9085914

Alghamdi, S. R., \& Bayaga, A. (2016). Use and attitude towards Learning Management Systems (LMS) in Saudi Arabian universities. Eurasia Journal of Mathematics, Science \& Technology Education, 12(9), 2309-2330. https://doi.org/10.12973/eurasia.2016.1281a

Alharbi, S., \& Drew, S. (2014). Using the technology acceptance model in understanding academics' behavioural intention to use learning management systems. International Journal of Advanced Computer Science and Applications, 5(1), 143-155. https://doi.org/10.14569/IJACSA.2014.050120

Al-Busaidi, K. A. (2013). An empirical investigation linking learners' adoption of blended learning to their intention of full e-learning. Behaviour \& Information Technology, 32(11), 1168-1176. https://doi.org/10.1080/0144929X.2013.774047

Al-Senaidi, S., Lin, L., \& Poirot, J. (2009). "Barriers to adopting technology for teaching and learning in Oman", Computers and Education, 53(3), 575-590. https://doi.org/10.1016/j.compedu.2009.03.015

Arora, A. K., \& Srinivasan, R. (2020). "Impact of pandemic COVID-19 on the teaching-learning process: a study of higher education teachers", Prabandhan: Indian Journal of Management, 13(4), 43-56. https://doi.org/10.17010/pijom/2020/v13i4/151825

Atef, H., \& Medhat, M. (2015). Blended learning possibilities in enhancing education, training and development in developing countries: A case study in graphic design courses. TEM Journal, 4(4), 358-365.

Berge, Z. L., \& Mrozowski, S. E. (1999). Barriers to Online Teaching in Elementary, Secondary, and Teacher Education, Canadian Journal of Educational Communication, 27(2), 59-72. https://doi.org/10.21432/T2P59B

Bervell, B., \& Umar, I. N. (2017). A decade of LMS acceptance and adoption research in Sub-Sahara African higher education: A systematic review of models, methodologies, milestones and main challenges. Eurasia Journal of Mathematics, Science and Technology Education, 13(11), 7269-7286. https://doi.org/10.12973/ejmste/79444

Bhalalusesa, R., Lukwaro, E. E., \& Clemence, M. (2013a). Challenges of using E-learning Management Systems Faced by the Academic Staff in Distance Based Institutions from Developing Countries: A Case Study of the Open University of Tanzania. Huria: Journal of the Open University of Tanzania, 14, 89-110. 
Bhatiasevi, V. (2016). An extended UTAUT model to explain the adoption of mobile banking. Information Development, 32(4), 799-814. https://doi.org/10.1177/0266666915570764

Buabeng-Andoh, C. (2012). Factors influencing teachers' adoption and integration of information and communication technology into teaching: a review of the literature, International Journal of Education and Development Using ICT, 8, 136-155.

Chen, R. J. (2010). Investigating models for pre-service teachers' use of technology to support student-centred learning, Computers and Education, 55(1), 32-42. https://doi.org/10.1016/j.compedu.2009.11.015

Cloete, A. L. (2017). Technology and education: Challenges and opportunities. HTS Theological Studies, 73(4), 1-7. https://doi.org/10.4102/hts.v73i4.4589

Coleman, E., \& Mtshazi, S. (2017). Factors affecting the use and non-use of Learning Management Systems (LMS) by academic staff. South African Computer Journal, 29(3), 31-63. https://doi.org/10.18489/sacj.v29i3.459

DHET, D. (2013). White Paper for Post-School Education and Training: Building an expanded, effective and integrated post-school system. Department of Higher Education and Training, Pretoria, South Africa.

Dobre, I. (2015). Learning Management Systems for a higher education-an overview of available options for Higher Education Organizations. Procedia-social and behavioural sciences, 180, 313-320. https://doi.org/10.1016/j.sbspro.2015.02.122

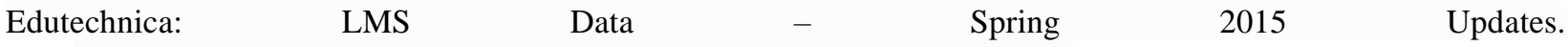
(2015). http://edutechnica.com/2015/03/08/lms-data-spring-2015-updates

Elmubark, A. Y., Cronje, J. C., \& Osman, I. M. (2013, May). A framework for investigating universities readiness for online learning: With particular reference to Sudanese universities. In 2013 IST-Africa Conference \& Exhibition (pp. 1-13). IEEE.

Embi, M. A., Abdul Wahab, Z., Sulaiman, A. H., Atan, H., Ismail, M., \& Mohd Nordin, N. (2011). E-learning in Malaysian higher education institutions: Status, trends, \& challenges. Department of Higher Education Ministry of Higher Education.

Emelyanova, N., \& Voronina, E. (2014). Introducing a learning management system at a Russian university: Students' and teachers' perceptions. International Review of Research in Open and Distributed Learning, 15(1), 272-289. https://doi.org/10.19173/irrodl.v15i1.1701

Evans, N. D. (2013). Predicting user acceptance of electronic learning at the University of Zululand (Doctoral dissertation, University of Zululand).

Evans, N., \& Mutula, S. (2015). Predicting the acceptance of electronic learning by academic staff at the University of Zululand, South Africa. Mousaion, 33(4), 1-22. https://doi.org/10.25159/0027-2639/697

Eynon, R. (2005). The use of the internet in higher education: Academics' experiences of using ICTs for teaching and learning. Aslib Proceedings, 57(2), 168-180. https://doi.org/10.1108/00012530510589137

Feller, J., \& Fitzgerald, B. (2000). A framework analysis of the open-source software development paradigm. In ICIS 2000 proceedings of the twenty-first international conference on information systems. Association for Information Systems, Atlanta, GA, 58-69.

Gasaymeh, A. M. M. (2017). University Students Use of WhatsApp and their Perceptions Regarding its Possible Integration into their Education. Global Journal of Computer Science and Technology, 17(1), 1-10.

Gikenye, W. (2012). The diffusion of mobile phones for Business and Information Management in Kenya. Journal of Gender, Information and Development in Africa (JGIDA), 1(1), 43-56.

Goh, T. T. (2013). A framework for multiplataform e-learning systems (Doctoral dissertation, Tese de Doutorado. Massey Univertsity. New Zeland. 2007. Disponível em :< http://mro. massey. ac. nz/handle/10179/1576>. Acesso em: 10 set).

Govender, D. (2018). Postgraduate Supervisory Relationship: Experiences at an Open Distance Learning Institution. International Journal of Education and Science, 20(1-3), 9-17. https://doi.org/10.31901/24566322.2018/20.1-3.02

Govender, I., \& Mkhize, M. (2015). E-Learning in Place of Face-to-face Lectures: An Exploratory Study of Students' Perceptions. Alternation Journal, 22(1), 183-203. 
Gratz, E., \& Looney, L. (2020). Faculty resistance to change: an examination of motivators and barriers to teaching online in higher education. International Journal of Online Pedagogy and Course Design, 10(1), 1-14. https://doi.org/10.4018/IJOPCD.2020010101

Haber, J., \& Mills, M. (2008). "Perceptions of barriers concerning effective online teaching and policies: Florida community college faculty". Community College Journal of Research and Practice, 32(4-6), 266-283. https://doi.org/10.1080/10668920701884505

Han, I., \& Shin, W. S. (2016). The use of a mobile learning management system and the academic achievement of online students. Computers \& Education, 102, 79-89. https://doi.org/10.1016/j.compedu.2016.07.003

Holtz, B., \& Krein, S. (2011). Understanding nurse perceptions of a newly implemented electronic medical record system. Journal of Technology in Human Services, 29(4), 247-262. https://doi.org/10.1080/15228835.2011.639931

Islam, A. N., \& Azad, N. (2015). Satisfaction and continuance with a learning management system: Comparing perceptions of educators and students. The International Journal of Information and Learning Technology, 32(2), 109-123. https://doi.org/10.1108/IJILT-09-2014-0020

Jansen, J. (2020). "“More Eyes on the Problem': What the Social Sciences and Humanities allow us to see and do in Response to COVID-19." South African Journal of Science, 116(7/8): Art. \#8501. https://doi.org/10.17159/sajs.2020/8501

Kasim, N. N. M., \& Khalid, F. (2016). Choosing the right learning management system (LMS) for the higher education institution context: a systematic review. International Journal of Emerging Technologies in Learning (IJET), 11(06), 55-61. https://doi.org/10.3991/ijet.v11i06.5644

Kaup, S., Jain, R., Shivalli, S., Pandey, S., \& Kaup, S. (2020). "Sustaining academics during COVID-19 pandemic: the role of remote teaching-learning". Indian Journal of Ophthalmology, 68(6), 1220-1221. https://doi.org/10.4103/ijo.IJO_1241_20

Keengwe, J., Onchwari, G., \& Wachira, P. (2008). The use of computer tools to support meaningful learning. AACE Journal, 16(1), 77-92.

Kent, C., Laslo, E., \& Rafaeli, S. (2016). Interactivity in online discussions and learning outcomes. Computers \& Education, 97, 116-128. https://doi.org/10.1016/j.compedu.2016.03.002

Khoza, S., \& Mpungose, C. (2018, July). Use of the Moodle curriculum by lecturers at a South African University. In ICEL 2018 13th international conference on e-Learning (p. 171). Academic Conferences and publishing limited.

Kibinkiri, E. L. (2014). The Role of E-learning on the Professional Development of Student-teachers in Cameroon (Doctoral dissertation, University of South Africa).

Kumar, D., \& Samalia, H. V. (2015). Learning management system adoption in universities-perception about moodle as a pedagogical tool in a private university in India. Editorial Advisory Board, 6, 169.

Kumar, S. K., Charan, M. P., \& Venkatamuni, R. R. (2020). Utilization of Moodle in Teaching Undergraduate Students in West Africa. Интеграция https://doi.org/10.15507/1991-9468.101.024.202004.552-560

Lansari, A., Tubaishat, A., \& Al-Rawi, A. (2010). Using a learning management system to foster independent learning in an outcome-based university: A gulf perspective. Proceedings of Issues in Informing Science and Information Technology, 73-87. https://doi.org/10.28945/1193

Lin, Y., Wang, S., Wu, Q., \& Chen, L. (2019). Key Technologies and Solutions of Remote Distributed Virtual Laboratory for E-Learning and E-Education. Mobile Networks and Applications, 24(1), 18-24. https://doi.org/10.1007/s11036-018-1130-z

Linna, P. (2013). Experiences of designing an e-learning training program collaboratively. IST-Africa 2013, 1-10.

Lloyd, S. A., Byrne, M. M., \& McCoy, T. S. (2012). Faculty-perceived barriers of online education. MERLOT Journal of Online Learning and Teaching, 8(1), 1-12.

Macfadyen, L. P., \& Dawson, S. (2010). Mining LMS data to develop an "early warning system" for educators: A proof of concept. Computers \& Education, 54(2), 588-599. https://doi.org/10.1016/j.compedu.2009.09.008 
Machado, M., \& Tao, E. (2007). Blackboard vs. Moodle: Comparing user experience of learning management systems. In 2007 37th annual frontiers in education conference-global engineering: Knowledge without borders, opportunities without passports (pp. S4J-7-S4J-14). IEEE. https://doi.org/10.1109/FIE.2007.4417910

Mahabeer, P., \& Pirtheepal, T. (2019). Online formative assessment tools: lecturers' experiences of using Moodle at a university in South Africa. Journal of Educational Studies, 18(1), 43-63.

Maina, M. K., \& Nzuki, D. M. (2015). Adoption determinants of e-learning management system in institutions of higher learning in Kenya: A Case of selected universities in Nairobi Metropolitan. International Journal of Business and Social Science, 6(2), 233-248.

Maphosa, V., Jita, T., \& Dube, B. (2020, June). Students' perception and use of Moodle as the E-Learning system implemented at a rural University in Zimbabwe. In EdMedia+ Innovate Learning (pp. 175-182). Association for the Advancement of Computing in Education (AACE).

Martins, J., \& Baptista Nunes, M. (2016). The temporal properties of e-learning: an exploratory study of academics 'conceptions. International Journal of Educational Management, $30(1), \quad 2-19$. https://doi.org/10.1108/IJEM-04-2014-0048

Masiello, I., Ramberg, R., \& Lonka, K. (2005). Attitudes to the application of a Web-based learning system in a microbiology course. Computers \& Education, 45(2), 71-185. https://doi.org/10.1016/j.compedu.2004.07.001

Mkhize, P., Mtsweni, E. S., \& Buthelezi, P. (2016). Diffusion of innovations approach to the evaluation of learning management system usage in an open distance learning institution. International Review of Research in Open and Distributed Learning, 17(3), 295-312. https://doi.org/10.19173/irrodl.v17i3.2191

Mlaba, S. M. (2020). An exploration of postgraduate lecturers' reflections on the use of Moodle in teaching business studies at the University of KwaZulu-Natal, South Africa (Doctoral dissertation).

Mpungose, C. B. (2020). Beyond limits: Lecturers' reflections on Moodle uptake in South African universities. Education and Termation 5033-5052. https://doi.org/10.1007/s10639-020-10190-8

Mpungose, C. B. (2017). Exploring lecturers' reflections on the use of moodle to teach physical science modules at a South African university (Doctoral dissertation).

Mpungose, C. B., \& Khoza, S. B. (2020). Postgraduate Students' Experiences on the Use of Moodle and Canvas Learning Management System. Technology, Knowledge and Learning, 1-16. https://doi.org/10.1007/s10758-020-09475-1

Mtebe, J. S., \& Raisamo, R. (2014). Investigating perceived barriers to the use of open educational resources in higher education in Tanzania. International Review of Research in Open and Distance Learning, 15(2), 43-65. https://doi.org/10.19173/irrodl.v15i2.1803

Mtebe, J. S., \& Raphael, C. (2018). Key factors in learners' satisfaction with the e-learning system at the University of Dar es Salaam, Tanzania. Australasian Journal of Educational Technology, 34(4), 107-122. https://doi.org/10.14742/ajet.2993

Mthethwa-Kunene, K. E., \& Maphosa, C. (2020). An Analysis of Factors Affecting Utilisation of Moodle Learning Management System by Open and Distance Learning Students at the University of Eswatini. Humanities, 5(1), 17-32. https://doi.org/10.20448/801.51.17.32

Murshitha, S. M., \& Wickramarachchi, A. P. (2016). An LMS usage assessment among students in a blended learning environment. Journal of Information Systems \& Information Technology (JISIT), 1(2), 1-7.

Mutsvunguma, G. (2019). Institutional repositories as platforms for open access in South African universities: the case of University of KwaZulu-Natal (Doctoral dissertation).

Mwalumbwe, I., \& Mtebe, J. S. (2017). Using learning analytics to predict students' performance in Moodle learning management system: A case of Mbeya University of Science and Technology. The Electronic Journal of Information Systems in Developing Countries, 79(1), 1-13. https://doi.org/10.1002/j.1681-4835.2017.tb00577.x

Nair, S. C., \& Patil, R. (2012). A study on the impact of learning management systems on students of a university college in Sultanate of Oman. International Journal of Computer Science Issues (IJCSI), 9(2), 379. 
Naresh, B., \& Reddy, B. S. (2015). Challenges and Opportunity of ELearning in Developed and Developing Countries-A Review. International Journal of Emerging Research in Management \&Technology, 4(6), 259 -262 .

Ohei, K. N., \& Brink, R. (2019). 'A framework development for the adoption of information and communication technology web technologies in higher education systems', South African Journal of Information Management, 21(1), a1030. https://doi.org/10.4102/sajim.v21i1.1030

Owolabi, K. A. (2017). Access and use of clinical informatics among medical doctors in selected teaching hospitals in Nigeria and South Africa. A PhD dissertation, University of Zululand.

Peralta, H., \& Costa, F. A. (2007). Teachers' competence and confidence regarding the use of ICT. Educational Sciences Journal, 3, 75-84.

Prottas, D. J., Cleaver, C. M., \& Cooperstein, D. (2016). Assessing faculty attitudes towards online instruction: a motivational approach, Online Journal of Distance Learning Administration, 19(4). https://www.westga.edu/ distance/ojdla/winter194/prottas_cleaver_cooperstein194.html

Poon, J. (2013). Blended learning: An institutional approach for enhancing students' learning experiences. Journal of online learning and teaching, 9(2), 271-288.

Punit, I. S., \& qz.com (2020). "For many of India's teachers, online classes amid lockdown have been an awful experience", Scroll.in, available https://scroll.in/article/961738/for-many-of-indias-teachers-online-classes-amid-lockdown-have-been-an-awfulexperience (accessed 23 August 2020).

Quadri, G., \& Garaba, F. (2019). Perceived Effects of ICT on Knowledge Sharing among Librarian in South-West Nigeria: A UTAUT Theoretical Approach. Journal of Balkan Libraries Union, 6(1), 38-46.

Ratheeswari, K. (2018). Information Communication Technology in Education. Journal of Applied and Advanced Research, 3(1), 45-47. https://doi.org/10.21839/jaar.2018.v3iS1.169

Rhode, J., Richter, S., Gowen, P., Miller, T., \& Wills, C. (2017). Understanding Faculty Use of the Learning Management System. Online Learning, 21(3), 68-86. https://doi.org/10.24059/olj.v21i3.1217

Rogers, E. M. (2003). Diffusion of innovations (5th ed.). New York: Free Press.

Rogers, E. M. (1995). Diffusion of Innovations, Fourth Edition. New York: Free Press.

Sackstein, S., Coleman, E., \& Ndobe, T. V. (2019). Lecturers' Perceptions of Learning Management Systems within a Previously Disadvantaged University. In Opening up Education for Inclusivity across Digital Economies and Societies (pp. 1-28). IGI Global. https://doi.org/10.4018/978-1-5225-7473-6.ch001

Sharma, A. K. (2020). “COVID-19: creating a paradigm shift in India's education system”, Economic Times Blog, available at: https://economictimes.indiatimes.com/blogs/et-commentary/covid-19creating-a-paradigm-shift-in-indias-education-system/. Accessed on 31 July 2020.

Subramanian, P., Zainuddin, N., Alatawi, S., Javabdeh, T., \& Hussin, A. R. C. (2014). A study of comparison between Moodle and Blackboard based on case studies for better LMS. Journal of Information Systems Research and Innovation, 6, 26-33.

Suleiman, A. A. (2011). Essentialities for e-learning: the Nigerian tertiary institutions in question. Academic Research International Journal, 1(2), 2011.

Sumak, B., Heričko, M., Pušnik, M., \& Polančič, G. (2011). Factors affecting acceptance and use of Moodle: An empirical study based on TAM. Informatica, 35(1), 91-100.

Sumak, B., Polancic, G., \& Hericko, M. (2010, February). An empirical study of virtual learning environment adoption using UTAUT. Paper presented at the 2010 Second international conference on mobile, hybrid, and online learning (pp. 17-22). IEEE. https://doi.org/10.1109/eLmL.2010.11

Surry, D. W. (1997). Diffusion Theory and Instructional Technology, [Online]. Retrieved, from http://www.gsu.edu/ wwwitr/docs/diffusion/

Taylor, C. R. (2002). "E-learning: the second wave", T and D, Vol. 56 No. 10, pp. 24-31. UNESCO (2020), COVID-19 Educational Disruption and Response, UNESCO, available at https://en.unesco. Org/covid19/educationresponse (accessed 16 June 2020). 
Trucano, M., Farrell, G., \& Isaacs, S. (2007). Survey of ICT and education in Africa: A summary report based on 53 country surveys. Washington DC: World Bank.

Tzeng, J. Y., \& Chen, S. H. (2012). College students' intentions to use e-portfolios: From the perspectives of career-commitment status and weblog-publication behaviours. British Journal of Educational Technology, 43(1), 163-176. https://doi.org/10.1111/j.1467-8535.2010.01165.x

Ulker, D., \& Y1lmaz, Y. (2016). Learning management systems and comparison of open-source learning management systems and proprietary learning management systems. Journal of systems integration, 7(2), 18-24. https://doi.org/10.20470/jsi.v7i2.255

Van de Heyde, V., \& Siebrits, A. (2019). The Ecosystem of e-learning Model for Higher Education. South African Journal of Science, 115(5/6), 1-6. https://doi.org/10.17159/sajs.2019/5808

Venkatesh, V., Morris, M. G., Davis, G. B., \& Davis, F. D. (2003). User acceptance of information technology: Toward a unified view. MIS Quarterly, 27(3), 425-478. https://doi.org/10.2307/30036540

Webbstock, D., \& Fisher, G. (2016). South African higher education reviewed: Two decades of democracy. Pretoria: Council on Higher Education.

Yuen, A. H., \& Ma, W.W. (2008), "Exploring teacher acceptance of e-learning technology", Asia-Pacific Journal of Teacher Education, 36(3), 229-243. https://doi.org/10.1080/13598660802232779

Zaharias, P., \& Mehlenbacher, B. (2012). Exploring User Experience (UX) in virtual learning environments. International Journal Hum.-Computer Studies, 70, 475-477. https://doi.org/10.1016/j.ijhcs.2012.05.001

\section{Copyrights}

Copyright for this article is retained by the author(s), with first publication rights granted to the journal.

This is an open-access article distributed under the terms and conditions of the Creative Commons Attribution license (http://creativecommons.org/licenses/by/4.0/). 